\title{
Peningkatan Keterampilan Pengolahan Pangan Sayuran Organik secara Online bagi Kelompok Rumah Sayur SKM (Suka Karya Makmur) di Desa Somongari, Kaligesing, Purworejo, Jawa Tengah
}

\section{Nurul Putrie Utami ${ }^{1 *}$, Hadi Sasongko ${ }^{2}$, Zuchrotus Salamah ${ }^{3}$, Purwanti Pratiwi Probosiwi 4}

${ }^{1}$ Program Studi Bisnis Jasa Makanan, Fakultas Ekonomi dan Bisnis, Universitas Ahmad Dahlan, Yogyakarta, Indonesia.

2 Program Studi Biologi, Fakultas Sains dan Teknologi Terapan, Universitas Ahmad Dahlan, Yogyakarta, Indonesia.

3,4 Program Studi Pendidikan Biologi, Fakultas Ilmu Pendidikan, Universitas Ahmad Dahlan, Yogyakarta, Indonesia.

Corresponding Email: nurul.putrie@culinary.uad.ac.id 1*.

\begin{tabular}{|c|c|}
\hline $\begin{array}{l}\text { Article History: } \\
\text { Received: Dec 31th } 2021 \\
\text { Revised: Jan 07th } 2022 \\
\text { Accepted: Jan 11th } 2022 \\
\text { Published: Jan 29th } 2022\end{array}$ & $\begin{array}{l}\text { Abstract: Somongari Village was an organic farming } \\
\text { location. Perishable vegetables require special handling } \\
\text { to increase shelf life. There was a need for training } \\
\text { which is expected to increase the knowledge and skills of } \\
\text { the member of Kelompok Rumah Sayur SKM (Suka } \\
\text { Karya Makmur), increase the selling benefit, and the } \\
\text { shelf life of organic vegetables products. The training } \\
\text { activities were processing vegetables from agricultural } \\
\text { products into bittermelon chips, eggplant chips, tomato } \\
\text { sauce, and chili sauce. The training began with product } \\
\text { processing through food processing videos } \\
\text { demonstration and then practiced it independently. } \\
\text { Evaluation of the results of this activity was carried out } \\
\text { in writing, verbally, direct observation of the process, } \\
\text { and evaluation of the food products made. The result of } \\
\text { this training is an increase in knowledge of participants } \\
\text { and from verbal interactions and direct observation, it } \\
\text { could be seen that the training materials can be } \\
\text { understood and can be practiced well by the trainees. }\end{array}$ \\
\hline
\end{tabular}




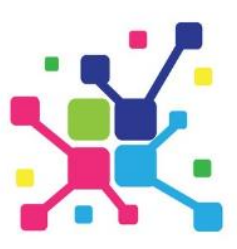

\section{Pendahuluan}

Saat ini seluruh negara, termasuk Indonesia, sedang menghadapi masalah pandemi yaitu Covid-19. Belum ditemukannya obat Covid-19 menjadikan masyarakat harus meningkatkan sistem kekebalan tubuh sebagai pertahanan dalam melawan bakteri, virus, dan organisme penyebab penyakit. Maka dari itu setiap orang perlu mengonsumsi makanan bergizi seimbang termasuk vitamin dan mineral. Sayuran adalah sumber vitamin, mineral, dan serat yang dapat berfungsi sebagai antioksidan untuk meningkatkan imunitas tubuh [1]. Masyarakat semakin menyadari pentingnya kesehatan. Sayuran organik mulai banyak dilirik karena dipercaya memiliki kandungan gizi yang lebih sehat tanpa zat kimia [2]. Walaupun harganya lebih mahal, sayuran organik tetap dicari oleh banyak orang. Pertanian organik merupakan suatu usaha yang memiliki peluang besar untuk bersaing. Pertanian organik merupakan sistem produksi yang menjaga kesehatan tanah, ekosistem, dan manusia [3].

Desa Somongari merupakan sebuah desa di Purworejo yang menjadi lokasi pertanian organik dengan memanfaatkan lahan pekarangan warga. Kelompok tani di Desa Somongari didominasi oleh ibu-ibu yang bekerja sebagai ibu rumah tangga. Kelompok tani ini diberi nama Kelompok Rumah Sayur SKM (Suka Karya Makmur). Pada penelitian Andriani, et al (2017) ditemukan bahwa pada sistem pertanian organik, petani merasakan pendapatan yang diterima lebih tinggi karena harga sayuran organik lebih tinggi jika dibandingkan dengan sayuran konvensional [4]. Hasil dari pertanian organik di Desa Somongari ini memiliki nilai jual yang lebih tinggi dibandingkan dengan hasil pertanian non organik sehingga dapat menjadi tambahan mata pencaharian dan sumber penghasilan bagi ibu-ibu kelompok tani.

Salah satu kelemahan pada produk sayuran adalah mudah rusak [5]. Sayuran harus didistribusikan dengan cepat agar saat akan digunakan masih segar. Petani dapat mengalami kerugian apabila distribusi terhambat. Agar hasil pertanian dapat dimanfaatkan secara optimal perlu adanya inovasi. Selain menjual hasil pertanian organik secara langsung, kelompok tani juga dapat mengolah hasil pertanian menjadi produk siap saji yang memiliki umur simpan lebih lama dan memiliki harga yang lebih tinggi.

Akibat adanya pembatasan kegiatan di masyarakat di dunia, terjadi penurunan perekonomian baik di Indonesia yang tentunya berdampak pada perekonomian di tingkat desa [6]. Hal ini terjadi karena tingginya pemutusan hubungan kerja (PHK) sehingga angka pengangguran meningkat pula [7]. Oleh karena itu, perlu adanya peningkatan jiwa kewirausahaan di tingkat desa sehingga mampu muncul semangat berwirausaha untuk memulai industri rumahan/ home industry sehingga dapat terbentuk usaha Mikro, Kecil dan Menengah (UMKM) dari kelompok tani organik di Desa Somongari. Dalam mencapai tujuan tersebut, perlu dilaksanakan pelatihan dalam pengolahan hasil tani organik untuk ibu-ibu agar termotivasi dan menumbuhkan jiwa wirausaha di Desa Somongari walaupun masih dalam masa Pandemi. 
Sesuai dengan kondisi pada Kelompok Rumah Sayur SKM (Suka Karya Makmur), maka perlu adanya pelatihan yang diharapkan mampu meningkatkan sumber daya manusia dari segi kemampuan dan kemauan Peningkatan skill pengolahan pangan akan meningkatkan pula produktivitas dan nilai ekonomi yang dihasilkan. Produk yang dipilih berupa keripik pare, keripik terong, saus tomat, dan saus sambal. Produk olahan ini memiliki daya simpan yang lama juga nilai ekonomi yang lebih tinggi dibandingkan dengan bahan baku.

\section{Metode}

a. Metode Pelaksanaan Kegiatan

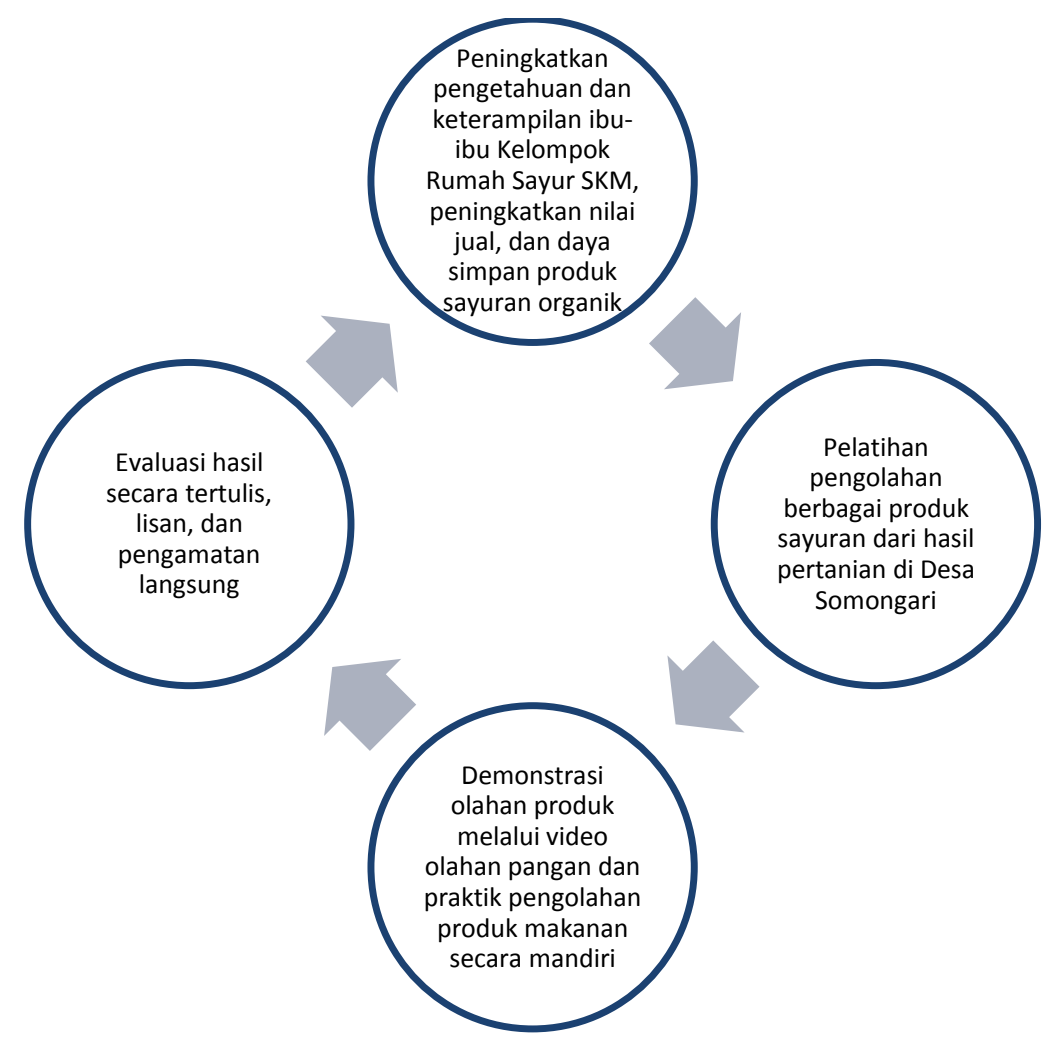

Gambar 1. Proses Perencanaan dan Strategi/Metode

Kegiatan pengabdian masyarakat tahun kedua Program Pengembangan Desa Mitra (PPDM) yang dilaksanakan hari Minggu, 18 Juli 2021 ini berupa kegiatan pelatihan pengolahan berbagai produk sayuran dari hasil pertanian di Desa Somongari. Pelatihan pengolahan pangan dari sayur ini dilaksanakan secara daring (dalam jaringan) dan hanya diikuti oleh 17 orang ibu anggota SKM sesuai anjuran pemerintah karena sedang ada aturan PPKM (Pemberlakuan Pembatasan Kegiatan Masyarakat) Jawa-Bali terkait Covid-19 sehingga kegiatan ini dibatasi dan dilaksanakan sesuai standar protokol kesehatan. Peserta pelatihan dari Rumah Sayur SKM dapat dilihat pada Gambar 2. 


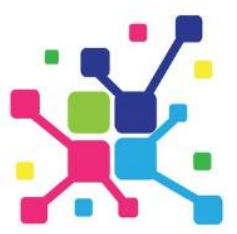

A J A D

Jurnal Pengabdian kepada Masyarakat

Vol. 2, No. 1, May, 2022, pp. 82-89

DOI : https://doi.org/10.35870/ajad.v2i1.42

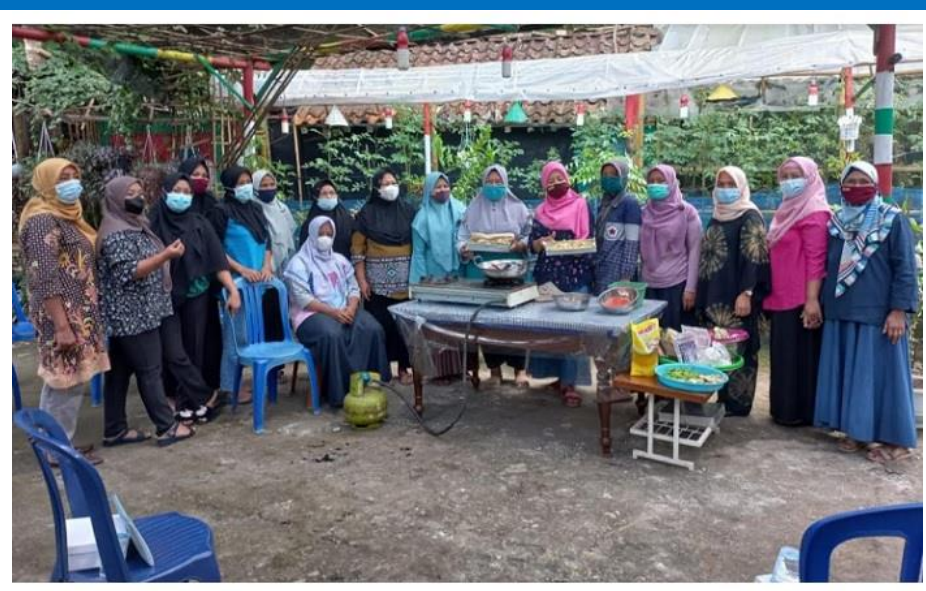

Gambar 2. Peserta Pelatihan Rumah Sayur SKM

Metode penyampaian dalam kegiatan pelatihan ini diawali dengan demonstrasi olahan produk melalui video olahan pangan kemudian dilanjutkan dengan praktik pengolahan produk makanan secara mandiri. Kegiatan pelatihan yaitu berupa pengolahan pangan dari sayuran organik yaitu keripik pare, keripik terong, saus tomat, dan saus sambal. Pada pelatihan jarak jauh ini menggunakan aplikasi video conference untuk melakukan pembimbingan langsung oleh tim seperti yang dapat dilihat pada Gambar 3.

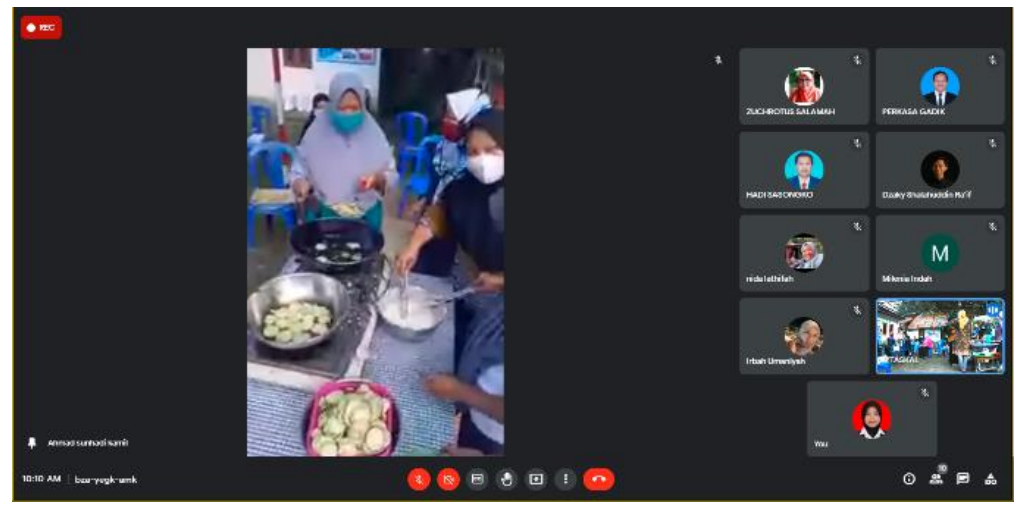

Gambar 3. Kegiatan Pelatihan Secara Online

Tujuan dari kegiatan pelatihan ini adalah meningkatkan pengetahuan dan keterampilan ibu-ibu Kelompok Rumah Sayur SKM, meningkatkan nilai jual, dan daya simpan produk sayuran organik. Sayuran merupakan kelompok makanan yang mudah rusak (perishable food) sehingga perlu perlakuan khusus setelah panen. Salah satu hal yang dapat mencegah kerusakan produk adalah dengan melakukan pengolahan makanan. Hal ini akan membuat produk dapat dimanfaatkan secara maksimal dan meningkatkan nilai ekonomi. Evaluasi hasil kegiatan ini dilaksanakan secara tertulis, lisan, dan pengamatan langsung dari proses dan hasil produk olahan makanan yang dibuat. Evaluasi tertulis dilakukan dengan pengisian soal tes pada sebelum dan sesudah pelatihan untuk mengetahui tingkat pengetahuan dengan media google form. Evaluasi secara lisan dilaksanakan dengan bertanya langsung pada peserta kegiatan saat kegiatan. Sedangkan untuk mengetahui tingkat keterampilan dari para peserta, dilakukan dengan mengamati proses praktik dan evaluasi hasil produk oleh pada peserta. 


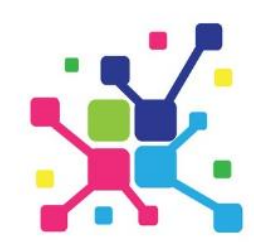

b. Waktu Efektif Pelaksanaan Kegiatan

Waktu kegiatan Program Pengembangan Desa Mitra (PPDM) dilaksanakan hari Minggu, 18 Juli 2021 berupa kegiatan pelatihan pengolahan berbagai produk sayuran dari hasil pertanian di Desa Somongari.

\section{c. Tempat Kegiatan}

Lokasi kegiatan Pelatihan pengolahan pangan dari sayur ini dilaksanakan secara daring (dalam jaringan) dan hanya diikuti oleh 17 orang ibu anggota SKM sesuai anjuran pemerintah karena sedang ada aturan PPKM (Pemberlakuan Pembatasan Kegiatan Masyarakat) Jawa-Bali terkait Covid-19 sehingga kegiatan ini dibatasi dan dilaksanakan sesuai standar protokol kesehatan.

\section{Hassil}

Kegiatan pelatihan pengolahan pangan dari sayuran organik berjalan dengan lancar. Walaupun kegiatan berlangsung secara daring (dalam jaringan), peserta mengikuti dengan antusias. Semua kegiatan mengikuti protokol kesehatan karena sedang dalam situasi PPKM (Pembatasan Pemberlakuan Kegiatan Masyarakat) Jawa Bali.

Tabel. 1 Peningkatan Pengetahuan Sebelum dan Sesudah Pelatihan

\begin{tabular}{ccc}
\hline & Rata-Rata & Rata-Rata \\
$\mathrm{N}$ & Sebelum Pelatihan & Sesudah Pelatihan \\
\hline 17 & 60 & 64 \\
\hline
\end{tabular}

Berdasarkan hasil penelitian diketahui bahwa pengetahuan dan keterampilan peserta mengalami peningkatan. Peserta mendengarkan penjelasan dan langsung melakukan praktik di lokasi masing-masing. Hasil dari kegiatan pelatihan ini adalah peningkatan pengetahuan dari peserta dengan nilai pre-test rata-rata 60 menjadi ratarata 64 setelah dilakukan pelatihan seperti yang bisa dilihat pada Gambar 2. Pada penelitian Hamad, et al., setelah dilaksanakan pelatihan untuk meningkatkan jiwa wirausaha, diketahui $76,65 \%$ peserta pelatihan berhasil dalam membuat produk yang sudah diajarkan [8]. Bahkan peserta dapat membuat budget perancangan anggaran saat pelatihan. Setelah pelatihan tersebut, peserta mampu melakukan pembuatan sendiri dan menjual produknya.

Pada interaksi secara lisan dan juga pengamatan langsung dapat diketahui bahwa materi pelatihan dapat dipahami dengan baik serta bisa dipraktikkan dengan baik pula oleh para peserta pelatihan. Beberapa peserta juga menyampaikan terima kasihnya dan mengungkapkan bahwa semakin meningkatkan motivasi untuk berbisnis olahan sayur sendiri. Beberapa pelatihan pengolahan pangan serupa juga terlihat memberikan dampak pada minat kewirausahaan seperti yang dilakukan di Kelurahan Tangkerang Tengah, Pekanbaru berupa olahan jamur tiram dan olahan singkong di Desa Palas, Pekanbaru $[9,10]$. 


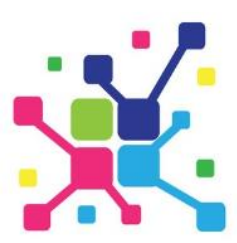

\section{Diskusi}

Pemberdayaan masyarakat untuk berwirausaha adalah hal yang seharusnya digalakkan saat ini selaras dengan semakin maju dan banyaknya bisnis yang penuh dengan inovasi. Kemandirian masyarakat perlu ditingkatkan agar dapat mengikuti jaman dan tidak bergantung kepada orang lain. Kewirausahaan dapat dibentuk dengan berbagai usaha seperti adanya pelatihan dan pembelajaran oleh calon pengusaha. Pada penelitian Susila, et al. (2020) pelatihan dengan berbagai pendekatan dapat memunculkan jiwa wirausaha [11]. Pendekatan yang dilakukan adalah menumbuhkan jiwa wirausaha, memberi pemahaman menjadi wirausaha yang sukses, pelatihan, dan pendampingan peserta. Oleh karena itu, peneliti melakukan pelatihan pengolahan pangan dari sayuran organik berupa keripik pare, keripik terong, saus tomat, dan saus sambal kepada ibu-ibu anggota Kelompok Rumah Sayur SKM di Desa Somongari, Kaligesing, Purworejo agar dapat menumbuhkan jiwa wirausaha dan meningkatkan pendapatan.

Secara keseluruhan, tujuan kegiatan pelatihan telah tercapai. Namun, tindak lanjutnya, masyarakat perlu mempraktikkan kekonsistenan hasil produk supaya bisa terstandar dengan baik. Kegiatan pelatihan berikutnya yang masih perlu dikuasai oleh peserta pelatihan adalah penentuan harga popok produksi (HPP) dan teknologi pengemasannya sehingga bisa menjaga kualitas produk hingga tangan konsumen $[10,12,13]$. Dengan tambahan pelatihan-pelatihan berikutnya diharapkan selain mampu menjadi tambahan penghasilan yang berkelanjutan bagi ibu-ibu anggota Kelompok Rumah Sayur SKM di Desa Somongari. Sehingga status ekonomi masyarakat akan meningkat dengan bermodalkan pengolahan hasil produk tani organik.

\section{Kesimpulan}

Kegiatan pelatihan pengolahan pangan dari sayuran organik yaitu keripik pare, keripik terong, saus tomat, dan saus sambal pada ibu-ibu Kelompok Rumah Sayur SKM (Suka Karya Makmur) dilaksanakan dengan lancar secara daring. Hasil dari kegiatan ini adalah ibu-ibu kelompok tani SKM meningkat baik pengetahuan maupun keterampilannya dalam mengolah produk hasil pertanian organik.

Walaupun dilaksanakan pada jumlah peserta yang terbatas dan daring, kegiatan dapat berjalan dengan baik. Pada kegiatan serupa dapat dilakukan dengan jangkauan yang lebih luas pada kalangan yang memiliki akses yang memadai sehingga kebermanfaatan menjadi lebih luas lagi. 


\section{Ucapan Terima Kasih}

Penulis mengucapkan terima kasih kepada Direktorat Riset dan Pengabdian Masyarakat Direktorat Jenderal Penguatan Riset dan Pengembangan Kementrian Riset, Teknologi dan Pendidikan Tinggi (Kemenristek Dikti) yang telah memberikan dana hibah pengabdian masyarakat melalui skema Program Pengembangan Desa Mitra (PPDM). Kami juga mengucapkan terima kasih kepada Universitas Ahmad Dahlan (UAD) terutama Lembaga Penelitian dan Pengabdian kepada Masyarakat (LPPM) UAD yang telah memberikan dukungan atas terlaksananya program ini.

\section{Daftar Referensi}

[1] Kemenkes RI. 2020. Panduan Gizi Seimbang pada Masa Pandemi Covid-19 "Lindungi Keluarga." Kementrian Kesehatan RI

[2] Crinnion WJ. 2010. Organic Foods Contain Higher Levels of Certain Nutrients, Lower Levels of Pesticides, and May Provide Health Benefits for The Consumer. Altern Med Rev, 15(1).

[3] Widowati LR, Setyorini D, Hartatik W, Purnomo J, Haryati U, Wiratno. 2018. Sistem Budi Daya Sayuran Organik. IAARD Press. Jakarta

[4] Andriani R, Kusumo B, Charina A. 2017. Analisis Keberlanjutan Praktik Pertanian Sayuran Organik Di Kecamatan Parongpong Kabupaten Bandung Barat. J Agribisnis Terpadu, 10(2), pp.129.

[5] Barth M, Hankinson TR, Zhuang H, Breidt F. 2009. Microbiological Spoilage of Fruits and Vegetables. In: Sperber W. DM, editor. Compendium of the Microbiological Spoilage of Foods and Beverages Food Microbiology and Food Safety. Springer. New York.

[6] Nasution DAD, Erlina, Iskandar M. 2020. Dampak Pandemi COVID-19 terhadap Perekonomian Dunia. J Benefita, 5(2), pp.212-24.

[7] PH L, Suwoso RH, Febrianto T, Kushindarto D, Aziz F. 2020. Dampak Pandemi Covid-19 Bagi Perekonomian Masyarakat Desa. Indones J Nurs Heal Sci.

[8] Hamad A, Pamungkas RB, Puspawiningtyas E. 2017. Peningkatan Jiwa Wirausaha Siswa Sma Melalui Pelatihan Teknologi Tepat Guna Pembuatan Nata De Coco. Abdimas Unwahas, 2(1), pp.9-15.

[9] Susi N, Rizal M, Mutryarny E. 2017. Pelatihan pengolahan jamur Tiram di Kelurahan Tangkerang Tengah Kecamatan Marpoyan Damai Kota Pekanbaru. Din Pengabdi Kpd Masy, 1(1), pp.79-83. 
[10] Khairani Z, Kamilah F, Aznuriyandi A. 2018. Peningkatan Daya Saing Produk Melalui Kreasi Makanan Berbahan Baku Hasil Pertanian Lokal. J Bakti Saintek J Pengabdi Masy Bid Sains dan Teknol, 2(1), pp.11.

[11] Susila, L.N., Haryanti, S.S. and Saryanti, E., 2020. Pelatihan Bisnis Online Guna Membangun Jiwa Wirausaha Generasi Muda. WASANA NYATA, 4(1), pp.29-32.

[12] Kasmi K, Candra AN. 2017. Penerapan E-Commerce Berbasis Business To Consumers Untuk Meningkatan Penjualan Produk Makanan Ringan Khas Pringsewu. J Aktual, 15(2), pp.109.

[13] Kusumawaty Y. 2018. Strategi Pemasaran Produk Makanan Ringan Khas Riau (Keripik Nenas dan Rengginang Ubi Kayu). J Agribisnis, 20(2), pp.124-38. 